\title{
THE GLOBAL BURDEN OF DIABETES: PREVALENCE, PREVENTION AND RECOMMENDATIONS
}

\author{
LA CARGA GLOBAL DE LA DIABETES: PREVALENCIA, PREVENCIÓN Y RECOMENDACIONES
}

Miguel A. Pérez, Ph.D., MCHES ${ }^{1, a}$, Jenette L. Smith, M.S. ${ }^{2, b}$

\begin{abstract}
RESUMEN
La carga mundial de diabetes, una de las principales causas de muerte, morbilidad y gastos en atención médica, ahora representa una de las mayores amenazas para la salud y el desarrollo mundiales. Los principales determinantes biológicos y de comportamiento de la diabetes son las dietas de azúcares y grasas procesadas, los bajos niveles de actividad física, el sobrepeso y la obesidad (Birn, Pillay, y Holtz, 2017). Como una de las cuatro principales enfermedades no transmisibles (ENT), Diabetes Mellitus (DM) ha atraído una gran atención por parte de las autoridades sanitarias mundiales. De hecho, la Organización Mundial de la Salud ha desarrollado una estrategia para abordar las crecientes tasas de DM, incluida la prevención, la gestión, el acceso a medicamentos esenciales y la vigilancia. Un enfoque integral que integre la política de atención médica, la promoción de la salud y la educación para la salud es necesario para la prevención y posterior tratamiento de la diabetes en todo el mundo.
\end{abstract}

Palabras clave: Diabetes mellitus; Política de salud; Estilo de vida; Promoción de la salud. (fuente: DeCS BIREME)

\begin{abstract}
The global burden of diabetes, a major cause of death, morbidity, and health care expenditures, now represents one of the greatest threats to global health and development. The main behavioral and biological determinants of diabetes are diets of processed sugars and fats, low physical activity levels, and overweight and obesity (Birn, Pillay, \& Holtz, 2017). As one of the four major non-communicable diseases (NCDs), Diabetes Mellitus (DM) has attracted a great deal of attention from global health authorities. In fact, the World Health Organization has developed a strategy to address increasing rates of DM including prevention, management, access to essential medicines, and surveillance. A comprehensive approach integrating health care policy, health promotion, and health education is necessary for the prevention and subsequent treatment of diabetes around the world.
\end{abstract}

Key words: Diabetes mellitus; Health policy; Lifestyle; Health promotion. (source: MeSH NLM)

\section{INTRODUCCIÓN}

In less than a generation, diabetes mellitus (DM) has become one of the most prevalent noncommunicable diseases affecting humans around the world. Jaacks, Siegel, Gujral, and Venkat Narayan (2016) concluded that "Diabetes, a major cause of death, morbidity, and health care expenditures, now represents one of the greatest threats to global health and development" ${ }^{\prime \prime}$. DM's impact on the global health status can be attributed to the 1.5 million deaths associated with it around the world each year ${ }^{2}$.
There is no question that DM rates are on the rise around the world. The World Health Organization (WHO) estimated that there are some 422 million adults living with diabetes in 2014, roughly 1 in every 11 persons $^{2}$, and that number is expected to increase to 642 million by $2040^{3}$ In fact, diabetes has become a "global menace," having increased in high-income countries (HICs) and low and middleincome countries (LMICs) by $45 \%$ since $1990^{3}$. Birn et al. (2017) continued to state, "In recent years, WHO's Commission on Social Determinants of Health (2008) has called for incorporating measures of health

\footnotetext{
${ }^{1}$ Fresno State. Department of Public Health, California-EE.UU.

${ }^{2}$ Clarkson College, Omaha, Nebraska- EE.UU.

a Professor and Internship Coordinator

b Doctoral Student
}

Quote as: Miguel A. Pérez, Ph.D., MCHES, Jenette L. Smith, M.S. The global burden of diabetes: Prevalence, prevention and recommendations. [Review Article].2019;19(2):00-00. (April 2019). DOI 10.25176/RFMH.v19.n2.2079

( ) Los autores. Este artículo es publicado por la Revista de la Facultad de Medicina Humana, Universidad Ricardo Palma. Este es un artículo de Open Access distribuido bajo los términos de la Licencia Creative Com- mons: Creative Commons Attribution 4.0 International(CC BY 4.0). (https://creativecommons.org/licenses/by/4.0/), que permite el uso no comercial, distribución y reproducción en cualquier medio, siempre que la obra original sea debidamente citadas. Para uso comercial, por favor póngase en contacto con revista.medicina@urp.pe 
inequity into planning, policy, and technical work, including data collection, at WHO and in member countries" ${ }^{\prime \prime}$.

In the US, according to the Centers for Disease Control and Prevention estimates, some 30 million Americans are living with diabetes, and of that number, 23.1 million had a diagnosis, and 7.2 million were undiagnosed ${ }^{4,5}$. Additional reports have stated that 1.5 million new cases of diabetes emerge each year within the U.S. population age 20 years or older, with significant disparities observed by race/ethnicity ${ }^{5}$. It is also estimated that $25.2 \%$, or 12.0 million seniors age 65 and older have diabetes, diagnosed and undiagnosed ${ }^{5}$. Regarding diabetes for Americans under the age of 20, approximately 19,300 are estimated to have diagnosed diabetes $^{5}$. In addition, in 2015, 84.1 million people age 18 and older had prediabetes in the US5. Graphic 1.

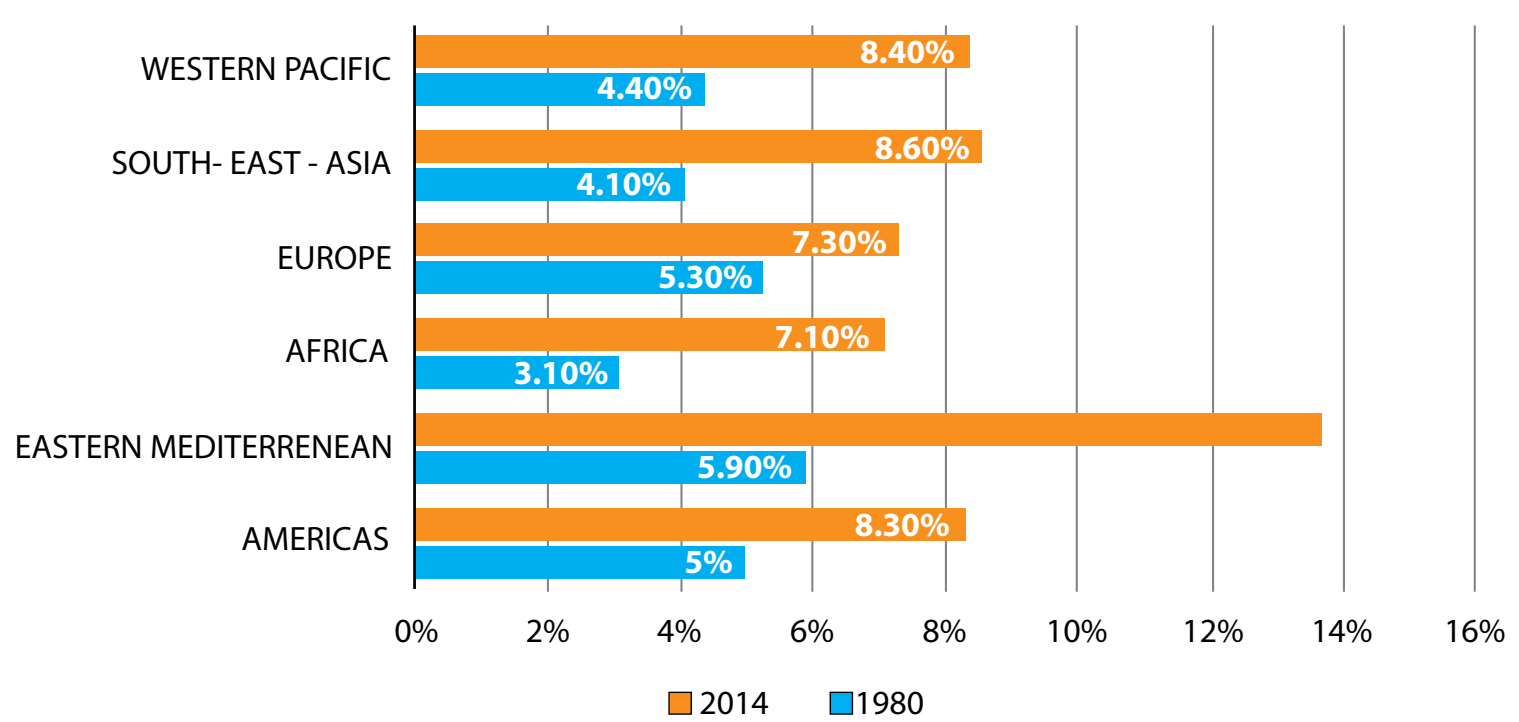

Graphic 1. Diabetes prevalence. Source: WHO, 2014.

Increased DM rates in LMICs present a serious economic and social challenge for individuals and nations. The WHO suggested that diabetes is a major cause of blindness, kidney failure, heart attacks, stroke and lower limb amputations around the world. "In pregnancy, poorly controlled diabetes increases the risk of fetal death and other complications" ${ }^{2}$, since individuals in LMICs may not have access to treatment or prevention strategies designed to reduce morbidity and mortality from the disease, those affected may experience preventable morbidity and mortality. Mills (2014) stated, "Lack of financial protection for the costs of health care means that approximately 100 million people are pushed below the poverty line each year by payments for health care, and many more will not seek care because they lack the necessary funds" ${ }^{\prime \prime}$. Birn et al. (2017) asserted that Type 2 diabetes is a largely preventable disease, and many of the ramifications of diabetes can be delayed, and possibly avoided completely ${ }^{3}$. Jaacks et al. (2016) stated that approximately one-half of those affected by diabetes world-wide are undiagnosed ${ }^{1}$.

\section{DISEASE OVERVIEW}

Diabetes mellitus is a metabolic disorder "characterized by disturbances in blood sugar regulation and metabolism" ${ }^{3}$ and occurs when the pancreas produces little or no insulin (Type 1), or when the body "cannot effectively use the insulin that the pancreas produces" (Type 2$)^{2,3}$. There are three types of diabetes: Type 1, Type 2, and gestational diabetes mellitus (GDM). The majority of diabetics, $90 \%$, have Type 2 diabetes $^{3}$.

Type 1 diabetes is a condition where the body's immune system destroys beta cells in the pancreas (cells responsible for insulin production). As a result, the pancreas produces little or no insulin leading patients to require daily insulin intake. The most common form of DM, Type 2, occurs when a person cannot effectively use the insulin that the pancreas produces $^{3}$. Type 2 diabetes is related to age, family history, physical inactivity, ethnicity, and in some cases results from GDM. 


\section{RISK FACTORS}

Birn et al. (2017) asserted that the main behavioral and biological determinants of diabetes are diets of processed sugars and fats, low physical activity levels, and overweight and obesity ${ }^{3}$. Beaubien (2017) stated that Type 2 diabetes is oftentimes considered a lifestyle, as it is much more likely to develop in people who are overweight ${ }^{7}$. Birn et al. (2017) stated that as modernization has occurred in countries, populations have been challenged with maintaining physical exercise levels and traditions of healthy eating, "due to the industrialization of agriculture, corporatization of food production (with local production shifted to export crops), global marketing of foods high in sugar and saturated fats, built environments designed for factory and service sector work" ${ }^{\prime \prime}$. In addition, Jaacks et al. (2016) stated, "The onset of type 2 diabetes is shifting to younger ages in most parts of the world, thus pediatricians should be trained to recognize the risk factors and intervene" ${ }^{\prime \prime}$.

\section{RESULTS - RECOMMENDATIONS}

As one of the four major non-communicable diseases (NCDs), DM has attracted a great deal of attention from global health authorities. In fact, the WHO has developed a strategy to address increasing rates of DM including prevention, management, access to essential medicines, and surveillance. Furthermore, the WHO (2016) has developed global systemic recommendations (Figure 1) designed to improve national capacity for prevention and control of $\mathrm{DM}^{2}$.

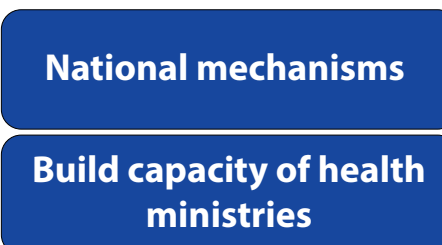

Prioritize prevention of overweight and obesity

\begin{tabular}{|c|}
\hline $\begin{array}{c}\text { Strengthen health } \\
\text { systems }\end{array}$ \\
\hline $\begin{array}{c}\text { Address gaps in } \\
\text { knowledge base }\end{array}$ \\
\hline $\begin{array}{c}\text { Surveillance and } \\
\text { monitoring }\end{array}$ \\
\hline
\end{tabular}

-Establish high-level multisectoral commissions.

- Strategic leadership, engagement of stakeholders, implement policies and foster accountability.

- Life-course approach, create supportive environments, use fiscal policies and legislation.

- Enhace capacity of primary health care, national protocols for management, improve access to affordable medicines.

- Outcome evaluations, operational research.

- Collect, analysis and use representative data, develop and strengthen diabetes registries if feasible.

Figure 1. National strategies, however, must be coupled with individual lifestyle recommendations and prevention methods in order to decrease DM rates around the world.

\section{PREVENTION METHODS}

\section{EATING HEALTHFULLY}

Consuming whole grains, which are rich in minerals and essential vitamins, two times per day may decrease the risk for Type 2 diabetes by up to $21 \%^{8}$. Similarly, decreasing refined grains and carbonated beverages (e.g., sodas) is recommended to decrease the chance of developing diabetes. Ross (2012) stated, "Because refined carbohydrates made from sugar and white flour rapidly increase insulin levels, they can permanently exhaust the pancreas (the insulinproducing organ), causing diabetes" ${ }^{\prime \prime}$. The author continued to note that eating large quantities of sugar can cause the loss of certain minerals, in particular, chromium. Experts also recommend limiting red meat consumption and replacing it with other forms of protein ${ }^{1,10}$. The US Office of Disease Prevention and Health Promotion documented recommendations for healthy eating patterns, including consumption of a variety of vegetables from all of the subgroups, fruits, whole grains, fat-free or low-fat dairy products, a variety of protein foods, oils, and limiting saturated fats, trans fats, added sugars, and sodium ${ }^{14}$.

\section{BEING PHYSICALLY ACTIVE}

A brisk walk on a daily basis can decrease the chance for Type 2 diabetes by $30 \%$. Current recommendations 
from the Centers for Disease Control and Prevention (CDC, 2018b), and the ODPHP (2019b) for physical activity include:

- For adults, at least 2 hours and 30 minutes each week of aerobic physical activity at a moderate level OR 1 hour and 15 minutes each week of aerobic physical activity at a vigorous level for adults 18-64. Adults should also engage in strengthening activities, like push-ups, sit-ups and lifting weights, at least 2 days a week ${ }^{15}$.

- For youth ages 6-17, 60 minutes or more of physical activity each day is recommended. Most of the 60 minutes should be either moderate or vigorous intensity aerobic physical activity, and should include vigorous-intensity physical activity at least 3 days a week. As part of their 60 or more minutes of daily physical activity, children and adolescents should include muscle-strengthening activities, like climbing, at least 3 days a week and bonestrengthening activities, like jumping, at least 3 days a week for children and adolescents ages 6-17

- The new ODPHP guidelines for children ages 3-5 years stated that children pre-school aged should be physically active throughout each day, aiming for at least 3 hours per day of active play, light, moderate, or vigorous intensity (ODPHP, 2019b) ${ }^{11}$.

\section{AVOIDING EXCESSIVE WEIGHT}

Excess weight increases the chances of diabetes seven times and up to 40 times for those who are obese. Decreasing body weight by $7-10 \%$ of weight can decrease risk for diabetes by $50 \%{ }^{5,12}$.
- Checking blood glucose. The American Diabetes Association (2018) recommends glucose screening for those under 45 and overweight with a risk factor such as sedentary lifestyle or a family history of diabetes ${ }^{5}$.

- Following medical advice.

\section{CONCLUSION}

In less than a generation, diabetes has become a growing global concern, with rates increasing by over $45 \%$ since $1990^{3}$. The authors continued to posit that the behavioral and biological determinants of diabetes include diets laden with fat and processed sugar, low levels of physical exercise, and overweight and obesity. A comprehensive approach integrating health care policy, health promotion, and health education is necessary for the prevention and subsequent treatment of diabetes around the world. As stated by Pasteur (1876), "Science knows no country, because knowledge belongs to humanity, and is the torch which illuminates the world"13.

Authorship contributions: The authors participated in the generation, collection of information, writing and final approval of the original article.

Financing: Self-financed.

Interest conflict: The authors declare no conflict of interest.

Received: December 14, 2018

Approved: February 18, 2019

Correspondence: Miguel A. Perez

Address: Department of Public Health. 2345 E. San Ramon Ave M/S MH30. Office: McLane Hall 184

Telephone: + 1 (559) 278-2897

E-mail:mperez@csufresno.edu 


\section{BIBLIOGRAPHIC REFERENCES}

1. Jaacks LM, Siegel KR, Gujral UP, \& Venkat Narayan, KM. Type 2 diabetes: A 21 st century epidemic. Best Practice \& Research Clinical Endocrinology \& Metabolism [Internet]. 2016; 30(3):331-43. Available from: http:// dx.doi.org/10.1016/j.beem.2016.05.003

2. World Health Organization. Global Report on Diabetes [Internet] 2016. Available from: https://apps.who.int/iris/bitstream/ handle/10665/204871/9789241565257_eng.pdf

3. Birn AE, Pillay Y, Holtz TH. Textbook of Global Health. 4th ed. S.I.: Oxford University Press; 2017.

4. Centers for Disease Control and Prevention. National Diabetes Statistics Report, 2017 [Internet]. 2018. Available from: https://www.cdc.gov/ diabetes/data/statistics-report/index.html.

5. American Diabetes Association. Statistics About Diabetes [Internet] American Diabetes Association. 2018. Available from: http://www. diabetes.org/

6. Mills A. Health Care Systems in Low- and Middle-Income Countries. The New England Journal of Medicine. 2014 Jul; 370:552-7.

7. Beaubien J. How Diabetes Got To Be The No. 1 Killer In Mexico [Internet]. National Public Radio. NPR; 2017. Available from:

https://www.npr.org/sections/goatsandsoda/2017/04/05/522038318/ how-diabetes-got-to-be-the-no-1-killer-in-mexico.

8. Sun Q, Spiegelman D, van Dam RM. White Rice, Brown Rice, and Risk of Type 2 Diabetes in US Men and Women. Archives of Internal Medicine. 2010; 170(16):961-9.
9. Ross J. The Diet Cure. New York: Penguin Books; 2012.

10. Knowler WC, Barrett-Connor E, Fowler SE. Reduction in the Incidence of Type 2 Diabetes with Lifestyle Intervention or Metformin. The New England Journal of Medicine. 2002; 346(6):393-403.

11. Centers for Disease Control and Prevention. Cancer Prevention and Control: Physical Activity Guidelines [Internet]. 2018. Available from: https://www.cdc.gov/cancer/dcpc/prevention/policies_practices/ physical_activity/guidelines.htm.

12. Shaw JE, Sicree RA, Zimmet PZ. Global estimates of the prevalence of diabetes for 2010 and 2030. Diabetes Research and Clinical Practice. 2010; 87(1):4-14.

13. Pasteur L. Top 25 Quotes by Louis Pasteur (of 125) [Internet]. A-Z Quotes. 1876. Available from: https://www.azquotes.com/author/11366Louis_Pasteur.

14. Office of Disease Prevention and Health Promotion (ODPHP) (2019a). Key recommendations: Components of healthy eating patterns. Retrieved from https://health.gov/dietaryguidelines/2015/guidelines/ chapter-1/key-recommendations/

15. Office of Disease Prevention and Health Promotion (ODPHP) (2019b). Top 10 things to know about the second edition of the physical activity guidelines for Americans. Retrieved from https://health.gov/ paguidelines/second-edition/10things/

Consulte la Versión Electrónica de la Revista: Facultad de Medicina Humana Universidad Ricardo Palma http://revistas.urp.edu.pe/index.php/RFMH<smiles>C1=[In]CC1</smiles> 